\title{
SOCIOLOGY IN COMMUNIST ROMANIA: AN INSTITUTIONAL AND BIOGRAPHICAL OVERVIEW
}

\author{
ȘTEFAN BOSOMITU ${ }^{1}$
}

\begin{abstract}
Suppressed on ideological grounds, banned as academic discipline, and dismantled as scientific infrastructure in the first postwar years, sociology was re-institutionalized in communist Romania during the 1960s, largely on political grounds. Subsequently, the discipline developed and augmented within an impressive scientific infrastructure - several university departments were established, research centres and facilities initiated, and specialized periodicals issued. Still, the prosperous period of Romanian sociology concluded after just one decade, through another political decision, which confined the study of sociology to post-graduate specialization and restricted research. My paper explores sociology's institutional infrastructure, as it was established after the discipline's renewal, focusing on the institutions created, but also on the biographical analysis of those involved within these processes. My paper will address the matter from a historical perspective, discussing the developments and the evolutions in the field by circumscribing to the political, cultural, and socio-economic contexts.
\end{abstract}

Keywords: communist Romania, history of social sciences, sociology, institutionalization.

It is easy to compile a descriptive history of the evolution of sociology in communist Romania. By 1948, sociology's interwar aggregated scientific framework was dismantled by several political decisions. The process was largely influenced by the general trend of the Soviet Bloc countries, which, under the influence of the Soviet Union, labelled sociology as a 'bourgeois' and 'reactionary' science, and subsequently banned it (Keen and Mucha, 1994:6). The case of Romania had its particularities, as the ideological and political repression over the discipline was also due to the controversial rapports between interwar sociology (mainly the Bucharest Sociological School) and the political power (Momoc, 2012), the allegiance of several sociologists to the

${ }^{1} \mathrm{PhD}$, Researcher, The Institute for the Investigation of Communist Crimes and the Memory of Romanian Exile, Bucharest, e-mail: stefan.bosomitu@gmail.com. 
Iron Guard (far-Right/Fascist Romanian interwar movement) (Boia, 2011; Momoc, 2012), and the active involvement of several other sociologists within the authoritarian regimes in Romania during World War II (Boia, 2011).

The ideological dogmatism and the implicit immobility diminished in the next decade, particularly during the Khrushchev thaw (Zemtsov, 1986; Weinberg, 2004). Sociology - as a term, regained its place within the public and academic discourse. In the following years, other advancements were made, the most important one referring to the resumed dialogue with the Western academics, which granted the Eastern scholars the chance to participate in international debates and institution building (Shalin, 1978). The evolution of sociology in Romania followed a pattern similar to the other Soviet Bloc countries - the emergence of a national professional organization, the establishment of the first university departments or research centres, and the appearance of specialized periodicals (Vorisek, 2008). The (Romanian) National Sociological Committee was established in 1959. A specialized periodical was issued a few years later, while the academic chairs and the research facilities were initiated after 1965.

My paper discusses the complicated process that led to the reinstitutionalization of sociology in communist Romania, and explores sociology's institutional infrastructure, as established after the discipline's renewal, focusing on the institutions created, but also on the biographical analysis of those involved in this process. The paper also addresses the matter from a historical perspective, discussing the developments and the advancements in the field by placing it within the political, cultural, and socio-economic contexts. I will further address some comments on the political, cultural, and ideological backgrounds that facilitated sociology's development in communist Romania, while also discussing the biographical trajectories of the main intellectual figures that participated in or just influenced these processes.

The central ideas I will address related to the aforementioned subjects refer to institutionalization as a complicated process, involving several initiatives and figures. The institutionalization refers to the progress achieved by the discipline within a certain framework, defined by teaching and research activities and the existence of a professional organization and of a coherent scientific/disciplinary discourse (advocated throughout specialized periodicals) (Vorisek, 2008). The simultaneous existence of these indicators defines the discipline as scientific. Based on this conceptual framework, Romanian sociology followed a tortuous and complicated path towards institutionalizations, marked by breakthroughs achieved over a couple of years - starting with the founding of a professional organization (1959), and concluded with the establishment of university departments (1966-1967). 
Another important stake of the paper relates to the complicated relationship between sociology and politics. Disbanded and subsequently banned, sociology was re-institutionalized in the 1960s as a re-imagined and re-contextualized scientific discipline. The process was largely influenced by the political arrangements, as the necessity to reconsider sociology was advocated rather from above, and only after instrumented also from below. The various initiatives of re-institutionalization (that will be further discussed) emerged from the academic field, but only after the regime clearly stated its opening towards such advancements. These initiatives, but also the professional and academic backgrounds of the actors promoting them, suggest developments that were rather an outcome of a quite complex process of negotiation and adaptation between the scientific field and state/party authority. Moreover, what may have seemed to be a competition between several academic projects, was also a contest for professional preeminence. Some of the protagonists of these processes endorsed a specific project, but managed to be later active supporters of another - a situation that proves the disputes rather converged towards authority, influence, and prestige.

In order to decipher the intricate process that led to the institutionalization of sociology, I will analyse the institutional development of the discipline, but also the biographies of the preeminent actors that influenced the process. The biographical analysis is relevant, as it may suggest a more nuanced and in-depth interpretation related to the different institutionalization initiatives, but also on the nature of the relationship established between the professionals and the political power. While indicating the professional/academic background, the biographical analysis also asserts the political resources each actor could depend on and mobilize. This evaluation seems to imply that the political resources have been preeminent within a system that leveraged loyalty, intended to control and regulate, while also limiting and obstructing a critical discourse.

The biographical analysis will focus on several subjects. A summary biographical overview on the National Sociological Committee (established in 1959) members is necessary in order to evaluate the first breakthroughs made in the field, as a consequence of an external pressure, that prompted another one - from above. The explicit political involvement, doubled by the institutional architecture it imposed circumscribed these first advancements to a political and diplomatic agenda, rather than a scientific one. Still, these evolutions created a context that allowed several initiatives from bellow (i.e. the academic field). A biographical survey on the main actors of these initiatives could be relevant, as it may suggest a nuanced perspective on the interactions between the academic and the political field, and indicate the relevance of the political 
resources one may employ within their scientific/academic project. With the establishment of university departments, sociology was fully institutionalized, and developed at an increased rate, while the scientific community managed to cover the 'blind spot' that had just occurred within the social sciences field. It is difficult to translate the cadres' selection that led to the assembly of the university departments. Without intending to propose an exhaustive perspective on the issue, I will try to exemplify the matter by discussing four case-studies - members of the sociology departments established within the University of Bucharest and 'Ștefan Gheorghiu' Academy.

\section{Breakthroughs}

A discussion related to the re-launch of sociology in communist Romania should not discount the moment that preceded and made possible the subsequent advancements in the field - the founding of a National Sociological Committee (NSC) in 1959 (T. B., 1962). The establishment of the NSC was not a private (individual or collective) initiative, but an assignment the regime commissioned to several high-ranking officials in the social sciences ${ }^{2}$. This project was authorized by the Romanian Workers Party (RWP)'s Central Committee's Internal Affair Section, which also imposed the future committee's membership - Athanase Joja (chairman); Mihail Ralea, Vasile Malinschi, and Petre Constantinescu-Iaşi (vice-presidents); Manea Mănescu (general-secretary); Andrei Oțetea, Constantin Ionescu-Gulian, and Tudor Bugnariu (members). In a similar manner, the NSC was instructed to affiliate to the International Sociological Association. The Central Committee's Internal Affair Section memorandum was not exclusively referring to sociology. The proposed NSC was only a part of a larger project that aimed to re-connect the Romanian scientific field within the international scientific networks and debates. To be more precise, the memorandum gave similar instructions regarding a 'projected' Society of Economic Studies - which was required to affiliate to the international organization subordinated to UNESCO. Thus, NSC had more of a diplomatic agenda, and not necessarily a scientific one. A brief overview of the academic and political biography of the NSC members gives substance to this argument.

Athanase Joja (1904-1972) was a philosopher and a logician, member of the Romanian Academy (1955), and Minister of Education and Culture - the institution in charge with the implementation of the NSC project. Senior member of the Communist Party (1935), Joja was sentenced and imprisoned during World War II on political grounds. In the postwar years, he occupied

\footnotetext{
2 National Archives of Romania (NAR), Fund Council of Ministers, Section Athanase Joja Cabinet, file 15/1959, p. 6: 'Address from the Central Committee's Internal Affairs Section'.
} 
important offices: Romania's permanent delegate to the UN (1955-1957) and vice-President of the Council of Ministers (1958-1960). His political influence and his prestige within the Romanian intellectual and academic field was to be validated by his nomination as the new President of the Romanian Academy a few months later (Dobre et al., 2004).

Mihail Ralea (1896-1964) was a philosopher, essayist, and psychologist, member of the Romanian Academy (1948), founder and director of the Academy's Institute of Psychology (1956). An intellectual with leftist sympathies, Ralea supported the new regime in the postwar years, being recompensed with influential offices and positions - he was Minister of Arts (1945-1946), and Romanian Ambassador to the USA (1946-1948). Even if he suffered minor setbacks in the early 1950s (especially after Ana Pauker's purge in 1952), Ralea managed to remain an influential intellectual, mostly due to his excellent rapports with Gheorghe Gheorghiu-Dej, general secretary of the RWP (Boia, 2011; Costea, 2001).

Vasile Malinschi (1912-1992) was an economist, with a $\mathrm{PhD}$ in economic studies defended in 1939 and a member of the Romanian Academy (1955). He was a senior member of the Communist Party (1930s), and occupied important offices in the postwar years - he was Rector of the Academy of Economic Studies (1949-1954), Minister of Inland Trade (1949-1954), and vice-president of the State Planning Committee (1954). Vasile Malinschi authored several important contributions on the industrial and agricultural developments in postwar Romania (Dobre et al., 2004).

Petre Constantinescu-Iași (1892-1977) was a historian, member of the Romanian Academy (1948), and founding member of the Communist Party (1921). In the postwar years, he was Minister of Propaganda/Information (19451946), Director of the 'Nicolae Iorga' Academy's Institute of History (1948-1953), and Minister of Religious Affairs (1953-1957). In 1959, Constantinescu-Iași occupied an influential office within the scientific and ideological field - as he was president of the National Committee of Sciences (1955-1974) (Ștefănescu, 1978).

Constantin Ionescu Gulian (1914-2011) was a Marxist philosopher and member of the Romanian Academy (1955). In 1959, Gulian was a professor at the University of Bucharest, head of the History of Philosophy Chair within the Faculty of Philosophy, and director of the Academy's Institute of Philosophy.

Andrei Oțetea (1894-1977) was a historian and member (and Head of the History Section) of the Romanian Academy (1955). He was a professor at the University of Bucharest, Head of the World History Department (1948-1964), and director of the "Nicolae Iorga" Academy's Institute of History (1957-1970) (Ștefănescu, 1978). 
Manea Mănescu (1916-2009) was an economist, and an unusual presence within this committee, as few could have foreseen his subsequent political career. Still, in 1959, Mănescu was a member of the communist nomenclature. He occupied important offices within the State Planning Committee and the Comecon (Dobre et al., 2004).

Tudor Bugnariu (1909-1988) was a Marxist philosopher, and member of the Romanian Academy (1955). Bugnariu was a senior member of the Communist Party (1934), and occupied several offices in the postwar years, focusing rather on his academic career. In 1959, he was a professor at the University of Bucharest, Dean of the Faculty of Philosophy (1958-1965) (Bosomitu, 2017).

The brief detour through the biographies of the NSC members was necessary in order to understand the Committee's pronounced mandate rather political (and also diplomatic) than scientific. The active interference of the political deciders altered the scientific framework of the 'new', 'reimagined' discipline, as it implied an unreasonable control over it. In addition, it is easy to notice that the academic background of the NSC members was only marginally linked to sociology - suggesting that the regime was not necessarily interested in a credible renewal of the discipline, but rather in a supervised and limited one. The regime's reluctance may have been caused by the stigma put on sociology in the past decade, and its pre-war (fascist) traditions, but also by a possible and hard to assess impact of Western theories. Thus, the 'new' sociology emerged - at least in 1959 - as a 'captive' science (Cotoi, 2011), as the regime chose to over-control it, by imposing the institutional framework and selecting its 'adequate' personnel. Furthermore, except for its activity abroad - Romanian delegations (generally including the same persons - officials of the NSC) participated at the ISA International Congresses in 1959 (Milano) and 1962 (Washington, DC) -, the NSC advanced no clear plan or program for an authentic and complete institutionalization of the discipline ${ }^{3}$. But the existence of the NSC was important as it restored sociology as a legitimate academic discourse, facilitating and promoting the further development of the discipline.

\section{Initiatives}

The re-institutionalization of sociology was decisively influenced by an external pressure, which determined an internal change. This external pressure refers to the advancements made in the field by the other socialist countries. In 1963, officials of the Central Committee's Science and Art Section

\footnotetext{
${ }^{3}$ NAR, Fund Council of Ministers, Section Athanase Joja Cabinet, file 15/1959, pp. 7-8: 'Statute of the People's Republic of Romania National Sociological Committee'.
} 
discussed and highlighted the Romanian Academy's underperformance in fields where the other socialist academies had advanced significantly - the case of 'concrete sociology' was emphasized 4 . This specific context authorized several initiatives that aimed at a further institutionalization of sociology (Rostás and Stahl, 2000). These initiatives were not necessarily distinct intellectual and scientific projects, but rather proposals to fill in a 'blind spot' that had appeared in the social sciences field.

Tudor Bugnariu, the Dean of the Faculty of Philosophy of the University of Bucharest, instrumented a first initiative. A Marxist intellectual, Bugnariu was born in 1909, in Budapest, in a Romanian family from Transylvania. After the end of World War I, his family returned to Transylvania - in Cluj, now province of the Kingdom of Romania. Bugnariu graduated the Faculty of Letters and Philosophy of the 'King Ferdinand' University in Cluj, with a major in sociology (1932). During his student years, Bugnariu adhered to the leftist/anti-fascist student circles. His political commitment became much more coherent in 1933, as he became a founding member of the Transylvania branch of the National Antifascist Committee. In 1934, he also adhered to the Communist Party, outlawed in Romania since 1924. The same year, his antifascist activity became a crime, as the Romanian authorities outlawed the National Antifascist Committee, considering it a 'communist' organization. Bugnariu was arrested in January 1935 and indicted in a process, which was highly publicized in the media. He was sentenced to one year in prison. Subsequently, he lost his job as a professor. After he was released from prison, Bugnariu continued his communist and antifascist activity, being once more sentenced to prison in 1937, and held into custody and detained in a concentration camp in 1940, on political grounds. After the end of World War Two, his militant biography granted him a public and academic career. Besides some political offices - he was mayor of Cluj (1944-1945), secretary of the Romanian Embassy in Belgrade (1947-1948), and Deputy Minister of Education (1956), Bugnariu focused on an academic career, as a professor at the University of Cluj (19481952; 1953-1956) and the University of Bucharest (1952-1953; 1958-1975) (Bosomitu, 2017).

Bugnariu's institutionalization project re-imagined sociology as closely linked to its interwar, autochthonous traditions. In this respect, he instrumented his project in collaboration with Traian Herseni and Henri H. Stahl - both of them former preeminent figures of the Bucharest Sociological School. A programmatic article signed by Bugnariu and Herseni advocated for

4 NAR, Fund Central Committee of the Romanian Communist Party, Agitprop Section, file 9/1963, pp. 35-37: 'Protocol of the Central Committee's Science and Art Section Meeting (November 4, 1963)'. 
a reclaim of the interwar traditions in sociology (1964). Although the authors acknowledged it as being 'idealistic', 'unscientific', and 'obsolete', they also claimed that some techniques and methods employed by the interwar sociology could and should be reconsidered. Moreover, the two authors asserted that the 'tradition of monographic researches' (characteristic to interwar sociology), was never lost, but evolved during the postwar years, assimilating a Marxist methodology (Bugnariu and Herseni, 1964: 7). The main problems related to this 'project' were its lack of political support, but also to the controversial figure of Herseni. Traian Herseni (1907-1980) was one of the most important members of the Bucharest Sociological School, but his political commitment to the far-right (fascist) Iron Guard was disapproved of in the postwar years - he was expelled from the University of Cluj (1945), arrested, sentenced, and imprisoned for his role in the 'national legionary' administration. He was released from prison only in 1956, being subsequently socially marginalized and forbidden to publish. He was partially 'recovered' by Mihail Ralea, who reintegrated him as a researcher within the Institute of Psychology (1958). Even if Herseni was allowed a gradual rehabilitation, his political past was never forgotten, nor forgiven (Boia, 2011; Costea, 2001; Momoc, 2012). The second major issue related to Bugnariu's project refers to the lack of political support. Bugnariu assumed that he would be supported in implementing his project by the Minister of Education and Culture - Ilie Murgulescu. Former comrades during the 1930s, both students with leftist and antifascist sympathies, Bugnariu and Murgulescu had collaborated in 1956 at the Ministry of Education - Murgulescu as Minister, Bugnariu as his Deputy. But the 1956 experience was rather unpleasant for both of them, as they were released from office and found responsible for the student unrests that had occurred in the context of the Hungarian Revolution ${ }^{5}$. Murgulescu would have been rather an obstruction in Bugnariu's plans, as he would have constantly postponed his initiative ${ }^{6}$.

As Bugnariu's project was delayed and eventually adjourned, other similar initiatives occurred. Ioan Drăgan advanced a significant one. Prototype of the 'new academic' (schooled within the communist educational system), Drăgan was cumulating important academic and public offices - at that time, Drăgan was associate professor of Historical Materialism at the Institute of Medicine and Pharmacy, and Director of the Social Sciences Sector within the Ministry of Education. Since he had been a student of the Faculty of Philosophy, University of Bucharest (1951-1955), Drăgan became a member

${ }^{5}$ NAR, fund Romanian Communist Party Central Committee - Chancellery, file 172/1956, pp. 25 ('Protocol of the Central Committee Politburo meeting - November 13, 1956').

${ }^{6}$ CNSAS Archives, fund Informational, file 124, vol. I, pp. 104-105. 
of the Communist Youth Union, and editor of the Propaganda Section within the Romanian Broadcast Service. After graduation, he was a lecturer within the Historical and Dialectical Materialism Chair at the Faculty of Philosophy, and deputy chief editor of Contemporanul - the most important cultural magazine in communist Romania. Moreover, in 1959, Drăgan became a member of the Communist Party 7 . Drăgan's initiative was not by definition a scientific one, but rather a political one. A significant program from 'below' was never formulated beyond the academic debates. Drăgan's peculiar status - he was both an academic, and a Party bureaucrat, allowed him to 'negotiate' the matter between the two sides.

\section{A Compromise}

Political deciders thus settled the dispute between the two competing 'projects'. A directive of the 1965 Communist Party Congress referred to the necessity to reconsider the importance of the 'field social investigations' or 'concrete sociology'. The person mandated to organize a roundtable gathering several professionals in the field -, was Drăgan ${ }^{8}$, and not Bugnariu a decision that proves the competition between the two was already settled. The event was quite important for the subsequent development of sociology. The roundtable decided on the future institutional framework of the discipline, established the 'new' sociology's main areas and directions of research, and concluded on the theoretical relationship between sociology and historical materialism. The debates also settled the place of sociology within the larger field of social sciences.

The roundtable gathered high-ranking officials (Mircea Biji, Director of the Central Statistics Directorate; Tudor Bugnariu, Dean of the Faculty of Philosophy, University of Bucharest; N.N. Constantinescu, Head of the Political Economy Department, Academy of Economic Studies; Petre Năvodaru, Deputy Director of the Central Statistics Directorate), former experimented sociologists (Henri H. Stahl, Traian Herseni, Gh. Dumitrescu - all of them members of the Bucharest Sociological School), and other social scientists from the fields of architecture, urban planning, demography, public health, anthropology, philosophy, medicine, and economics. The debates concluded on the degree of autonomy of sociology in relation to the official ideology in general, and to historical materialism in particular. The re-imagined sociology was to be subordinated to historical materialism, defined as 'the theoretical and methodological basis of social field research'. More precisely, sociology was

\footnotetext{
${ }^{7}$ NAR, fund Romanian Communist Party Central Committee - Cadre Section, file D/728, passim.

8 'Sociological Research - Roundtable', in: Contemporanul, no. 29(979), July 16, 1965.
} 
mandated to 'thoroughly analyse the quantitative determinations of the social process', offering thus ' $a$ solid support for the qualitative theoretic analysis' ${ }^{9}$ of historical materialism. During the debates, other important details were asserted. Unexpectedly, Tudor Bugnariu was the only one to refute the advocated importance of the 'autochthonous traditions' in sociological research - claiming that the 'new' sociology should not be narrowed to 'monographic research'. Another important outlook in regard to the 'future' discipline was argued by Herseni, who recommended that all the programs of 'social planning', 'social construction', and 'social amelioration' should be preceded by extensive projects of 'social diagnose'. The discussions also formulated, determined, and authorized sociology's anticipated main areas of research - most of these related to the major reconfiguration the Romanian society experienced in the previous two decades. They argued for the necessity of researches related to the urbanization, industrialization, and collectivization processes, and their social impact: population dynamics (exodus from rural towards urban areas), the management of production, labour productivity, community life, the workers' time budgets. In addition, sociological investigation was to grant special attention to subjects related to family, population (demography, health and hygiene studies), education, culture, or public opinion ${ }^{10}$.

The roundtable debates concluded on three major issues: the necessity to advance and intensify the 'concrete sociological research'; the need to guarantee an adequate institutional framework of the discipline - a Centre for Sociological Research was planned, along with other departments of sociology within the already existing research institutes; the urgency for training and qualifying specialists - in this regard, a Department of Sociology was to be established within the Faculty of Philosophy, University of Bucharest. All these three issues were to be promptly implemented. The importance of sociology and the subsequent necessity to reconsider it was validated by the resolutions of the 9th Party Congress (July 1965). A Centre for Sociological Research, subordinated to the Romanian Academy, was founded in the summer of 1965, while the Department of Sociology was established one year later at the Faculty of Philosophy.

A biased and unilateral perspective on the evolution of sociology between 1959 and 1965 could suggest an unrestricted control the political power claimed over the re-emerging discipline. Although the regime's deciders intended to regulate and supervise the 'new' sociology, its progress during these years was rather an outcome of a quite complex process of negotiation and adaptation between the scientific field and state/party

\footnotetext{
${ }^{9}$ Ibid.
}

10 Ibid. 
authority. The 'success' of Drăgan's initiative suggests such a thesis, as beyond his political mandate, he was, in fact, merely an ingenious mediator between the two sides. The authorities favoured Drăgan's initiative just because he was able to better negotiate the matter, encompassing both the authorities 'instructions' and the scientific field's expectations. By contrast, Bugnariu never succeeded to compromise on this 'necessary' dialogue between authorities and the scientific field, disapproving of the political interference on the matter. In fact, after the Centre for Sociological Research was established in 1965, with him not being involved in the process, he rejected the new institution, which he considered nothing more than a 'propaganda institute'11. And still, the post1965 progress and transformation of sociology could have unfolded as a compromise between the two 'competing' initiatives. But Bugnariu's career was to face some major interferences during 1965. The political changes occurred in 1964-1965 (the RWP Memorandum in April 1964, which asserted the end of the USSR hegemony over Romania; the death of Gheorghe Gheorghiu-Dej in March 19, 1965; and the rise to power of Nicolae Ceaușescu) inspired ample debates among the students - including those of the Faculty of Philosophy. Faced with a situation considered alarming and unstable, the authorities overreacted, ordering a thorough investigation of the Securitate. Bugnariu, Dean of the Faculty, denounced the regime's excesses, standing by his students. As a consequence, he was statutory penalized by the University Party organization, being later dismissed from office (Blaga, 2012; Ianoși, 2012). Constantin Nicuță capitalized on the situation, being appointed as new Dean of the Faculty of Philosophy. Nicuță (1906-1991), a sociologist and philosopher, had been professor at the Faculty of Philosophy since 1963. He graduated from both the Faculty of Law and the Faculty of Letters and Philosophy (1932) - the latter with a major in sociology. Lecturer at the Faculty of Iași (1930s), he was dismissed due to his political (leftist) sympathies. After World War II, Nicuță had an impressive career, occupying both academic and public offices. He was appointed professor of historical materialism at the University of Iași (1946), general secretary of the Institute of Romanian-Soviet Studies (1948-1951), professor at the 'A. A. Zhdanov' Party's Superior School (1951-1956), deputy minister of Education (1956-1958), Ambassador of Romania in Vienna (1958-1959), Chief of the Romanian delegation to the UN (1959-1960), and Ambassador of Romania in Paris (1960-1963) (Costea, 2001). In 1965, after he was appointed as the new Dean of the Faculty, Nicuță took full advantage of the possibility in order to impose his influence over the

11 CNSAS (National Council for the Study of the Securitate Archives) Archives, fund Informational, file 124, vol. I, pp. 75-77. 
emerging sociology. The plausible 'negotiations' between him and Drăgan settled with a compromise: two chairs of sociology were to be established within the Faculty of Philosophy, one ruled by Drăgan, the other by Nicuță. This status quo was soon to be interfered with by the re-ascent to power of an intellectual and former leading figure of the Communist Party - Miron Constantinescu, who was to be rehabilitated by the new regime.

Miron Constantinescu (1917-1974) was a Marxist intellectual, senior member of the Communist Party (1936), and a former associate of the Bucharest Sociological School. He graduated from the Faculty of Letters and Philosophy of the University of Bucharest (1938) - with a major in Sociology. He participated in the former monographic campaigns of Gusti's school (19381939), and was a member of its informal leftist faction, along with Henri H. Stahl, Mihai Pop, Dumitru Corbea, Roman Moldovan, Gheorghe Retegan, Tudor Alexandru Stoianovici, etc. Imprisoned during World War II for communist activity, Constantinescu became an important member of the Communist Party leadership, occupying influential offices during the first postwar decade. He was the chief editor of the Party's official newspaper, Scânteia/The Spark (19441945); secretary of the Bucharest Party organization (1945-1946); secretary of the Democratic Parties' Bloc (electoral alliance dominated by the Communist Party) - from this position, Constantinescu was in charge with the coordination of the electoral campaign (1946); Minister of the Mines and Petroleum (19481949); president of the State Planning Committee (1949-1955). Constantinescu also became a leading figure of the Communist Party - member of the Central Committee (1945-1960), of the Politburo (1945-1957), and of the Secretariat (1952-1954). In 1957, he was purged and removed from office, after a dispute with the general secretary of the Party, who considered it a de facto putsch attempt. He was later marginalized by the Gheorghiu-Dej regime - a situation that allowed him to resume his intellectual career. Constantinescu was rehabilitated by Nicolae Ceausescu after 1965, regaining an important political capital (Bosomitu, 2015). Constantinescu became the promoter and the protector of the 'new' sociology - mediating the complex relation between it and the regime's deciders. While his political statute granted the discipline a prevalence among the other social sciences (Kolaja, 1974; Tismăneanu, 2004), Constantinescu's influence over sociology also prevented an independent development of the discipline. He always sought to control and regulate the field, imposing themes and areas of research, authorizing or delaying promotions, and even disallowing certain former members of the Bucharest Sociological School to reconnect with the 'new' sociology (Bosomitu, 2015).

The three initiatives aforementioned were not strictly distinct academic projects, and never competed one against the other, but merely emerged in 
specific contexts. All the three initiatives acknowledged the same opportunity, but challenged it in different manners. It is quite obvious that Bugnariu's project had a primacy - due to its representative's academic positions. But Bugnariu's inability to capitalize on the situation, doubled by his reluctance and (even) insufficiency towards a negotiation with the political deciders adjourned and later annulled his efforts. In this specific context, a 'new' initiative arose, that mediated the 'necessary' dialogue between the academic and the political field. This project did not contest the previous one - as it included initially its promotors (Drăgan's roundtable involved Bugnariu, Herseni, and Stahl). Bugnariu's 'fall' in 1965 allowed Nicuță to interfere with what could have been a compromise. Constantinescu's re-ascent to power revoked the established status quo, but never challenged it. He only assumed a primacy over the field, acknowledged by the others. Still, every initiative may have advanced in a distinct manner, if were it not to be intruded by the subsequent one. We may assume that Bugnariu's sociology could have developed assuming the monographic traditions of the Bucharest Sociological School, while also reclaiming its former cadres. In the same manner, Drăgan's project could have unfolded as an uncritical and compliant discipline, as it assumed a compromise between the field and the political deciders, that Bugnariu considered was unreasonable. Miron Constantinescu's interference within the field may be perceived as a reinforcement of this political control over sociology. Paradoxically, his political status granted the discipline a degree of autonomy, almost impossible to be attained by the previous projects. 'Ruled' by Miron Constantinescu, sociology became a privileged social science, and it acquired an explicit assignment - to assist the political deciders with major societal projects (urbanization, industrialization) by providing the required information and data. The continuities and interconnections between the three initiatives, and the fact that the three never competed one against the other, allowed a fluency of professionals and ideas. The case of Henri H. Stahl is illustrative, as he was an integral presence within the three projects. Certainly, his role and his involvement was neither similar, nor proportionate.

\section{The institutional development}

By the late 1960s sociology was a fully institutionalized academic discipline in Romania - with a professional association, departments within the major universities, an important research infrastructure (research institutes, laboratories), and several specialized periodicals.

The institutional development of sociology comprised both teaching units (university departments) and research units (departments, laboratories). 
The first university departments were established in 1966 - at the Faculty of Philosophy, University of Bucharest (Constantinescu and Grigorescu 1970), and at the Faculty of Philosophy and Political Sciences of the 'Stefan Gheorghiu' Academy of Social and Political Studies (the party's superior school) (Iordăchel, 1970). One year later, similar departments were instituted within the other two major universities in Romania: a Department of Philosophy-Sociology, at the 'Babeș-Bolyai' University of Cluj (Kallós and Roth 1970), and a Department of Psychology-Sociology, at the 'Alexandru Ioan Cuza' University of Iași (Bărbat, 1970). Subordinated to these departments, several sociological laboratories - with specific research tasks (mainly field investigations), were founded: in 1966 within the University of Bucharest, in 1968 at the universities of Cluj and Timișoara, and later in Iași (Costea et al., 2006). Other institutions - with specific research assignments, were subordinated to the Romanian Academy. The first significant example is the Sociological Research Centre, founded in 1965, but also the Department of Sociology, established within the Romanian Academy's Institute of Philosophy - which carried out research in the field of industrial sociology, rural sociology, mass culture sociology, the theory of social development, and the sociology of nation (Cernea, 1970). Similar departments were later instituted within the Centres for Social Sciences in Cluj, Iași, and Timișoara.

Research units and facilities were also established outside the academic sphere. In 1968, a Research Centre for Youth Problems was founded, as a governmental agency, subordinated to the Ministry of Youth Affairs. The Centre's main objective was the study of youth considered as a dynamic social category in the process of its formation and integration into work and life (Bădina, 1970: 6364). The Centre comprised several interdisciplinary teams (sociology, ethics, pedagogy, psychology, philosophy, statistics), that approached different themes of research, with a specialist of the Centre working simultaneously on different projects. The main themes addressed by the Centre's researchers dealt with youth and labour, youth and socio-political life, youth and family, sociology of youth, etc. (Bădina, 1970a; Bădina 1970b; Schifirneț, 1999).

The main purpose of this impressive infrastructure stemmed from the need of the party to comprehend the 'new social'. During the previous two decades, the Romanian society experienced massive reconfigurations - the industrialization and urbanization processes, the collectivization of the agriculture, massive migration from the rural towards the urban areas, which restructured the anterior societal foundations. Sociology was thus called to understand and then decipher the consequences of these processes, to discern the nature of this 'new social', but also to provide solutions to overcome the regime's problems and impasses. More precisely, the main purpose of sociology was not 
necessarily to reveal the regime's dysfunctionalities, but rather to discuss them, and offer solutions in order to surpass them. But the conclusions and/or solutions provided by the sociological surveys - when (and if) it was requested -, were frequently acknowledged with extreme caution and even with suspicion by the decision-makers. This situation was a result of the unbalanced relationship between the scientific field, the party's bureaucratic apparatus, and the party's decision makers, and the latter's scepticism towards the scientific narrative that could have implied a 'critical' discourse. Moreover, Miron Constantinescu's political past - purged for attempting a putsch over the secretary general of the party, and his deep implication and almost complete control over sociology may have indicated that his agenda was not solely scientific. In fact, there is an apocryphal mention that states an explicit accusation formulated against Constantinescu, claiming that he was trying to use sociology to magnify his political ambitions. (Mihăilescu and Rostás, 2007).

\section{Professionals, cadres, networks}

A major issue related to the newly institutionalized discipline refers to the lack of professionals in its field. At the end of the 1960s, when sociology's institutional and scientific infrastructure was rapidly expanding, there were several former professionals of the discipline - 'survivors' of the former Bucharest Sociological School. With minor exceptions, none of them played a consequential role within the process. Except Henri H. Stahl - already mentioned, the 'new' sociology excluded figures such as Traian Herseni, Mihai Pop, Octavian Neamțu, Vasile Caramelea, Gheorghe Retegan, etc. In the cases of Traian Herseni, Gheorghe Retegan, Octavian Neamțu the regime's continuous reluctance to engage with stigmatized former sociologists was discernable. As mentioned before, Herseni's fascist past was never forgotten, nor forgiven, while Retegan and Neamțu were stigmatized as they had been indicted (Retegan even sentenced) in a major postwar political trial (Betea, 2011). As for the others, as their postwar careers were already obstructed, they 'migrated' towards other disciplines, and preferred to continue their activity within those specific fields: Caramelea in anthropology, Pop in ethnology and folklore.

Many of the individuals that were appointed within the newly instituted departments of sociology were philosophy or psychology graduates. Their academic background was only incidentally linked to sociology. The department of the University of Bucharest was an exception, as it included Henri H. Stahl, a leading figure of interwar Romanian sociology. Some argued that at the beginning, the professors were learning along with their students (Mihăilescu and Rostás, 2007). In order to overcome this fact, the authorities facilitated international 
dialogue and exchange, through conferences and workshops, but mainly through fellowships awarded to many of the new and young professionals, mostly within Western universities (Bosomitu, 2015). The sociology departments were thus formed and supplied with a mixture of academics (professionals with an exclusive academic background) and apparatchiks (professionals that also had important careers within the party bureaucratic apparatus). Without attempting to suggest a comprehensive overview on the matter, I will exemplify these issues through several cases which reveal some patterns.

Aurelian Bondrea (b. 1928) was, similar to Ioan Drăgan, the prototype of the 'new academic'. After 1944, he became a member of the Communist Youth Union, and a member of the Communist Party (1946). Subsequently, he became a party activist, occupying several unimportant offices: director of a community centre, instructor of a County Party Organization, editor of a regional Party newspaper. In 1953, he was accepted as a student of the Instructors Party School, being later employed as an activist of a Regional Party Committee's Agitprop Section (1953-1960). Meanwhile, he graduated (without attendance) the Party Superior School, receiving a Bachelor Degree in Philosophy. After obtaining a PhD diploma in philosophy in 1964 - still within the Party Superior School - he was promoted as an instructor of the Central Committee's Agitprop Section (1964-1968). In 1968, he was employed secretary of a municipal party organization. Meanwhile, he was also a member of the scientific council of the Faculty of Philosophy of the 'Ștefan Gheorghiu' Academy (the former Party Superior School). In 1969 he returned to Bucharest, where he was appointed lecturer at the Department of Sociology (University of Bucharest), and deputy general director of the Directorate of Higher Education within the Ministry of Education. In 1970, he was the beneficiary of an eight-month academic exchange program in France ${ }^{12}$. Within the Department of Sociology, Bondrea taught a course on the sociology of mass-media (Constantinescu and Grigorescu, 1970).

Petre Cristea (b. 1929) had a comparable trajectory. A former steelworker at the Hunedoara Steel Plant (1950), he was selected to attend a two-year Party School, which gave the workers the chance to continue their studies, and in 1952 he was accepted at the Faculty of Philosophy, University of Bucharest. After graduating - with a major in psychology, he was employed within an evaluation centre for juvenile delinquents, of the Ministry of Interior (1957). In 1959, he was appointed as chief of cabinet of the department of historical and dialectical materialism within the Institute of Medicine, and subsequently as a lecturer (1960). In 1964, he was enrolled within a doctoral program at the Party Superior School and, after obtaining his $\mathrm{PhD}$ in

\footnotetext{
12 NAR, fund Romanian Communist Party Central Committee - Cadre Section, file B/982, passim.
} 
philosophy (1968), he was appointed lecturer at the Department of Sociology, University of Bucharest. In 1970, he was in charge of the seminars on methods and techniques of research ${ }^{13}$.

Aculin Cazacu's (b. 1939) intellectual and professional career falls into a totally different category. He had an almost exemplary professional trajectory and, until his appointment as a lecturer within the Department of Sociology, University of Bucharest - he had only incidental contacts with the party spheres and the party bureaucratic apparatus. After graduating the Faculty of Philosophy (1961), he was employed at the Institute for Pedagogical and Psychological Research. In 1967, he was appointed as a lecturer within the Department of Sociology. He also beneficiated of a six-month academic exchange program at the University of Brussels (1970-1971). In 1969, he became a member of the Communist Party, but he never occupied offices within the party's bureaucratic apparatus ${ }^{14}$.

A similar example is Ion Iordăchel (b. 1933). Student of the Faculty of Philosophy of the University of Iași (since 1951), Iordăchel was selected within a larger group of students that were to continue their studies in the Soviet Union. He graduated from the University of Leningrad (1957) with a bachelor degree in philosophy. Upon returning to Romania, he was employed as a lecturer in social sciences at the University of Medicine in Bucharest. In 1963, Iordăchel was accepted within a doctoral program at 'Lomonosov' University in Moscow. In 1965, he defended his PhD in sociology. He was later employed at the Faculty of Philosophy, University of Bucharest, and, since 1967, within 'Ștefan Gheorghiu' Academy, where he was appointed chief of the Department of Sociology (1971) 15 .

These case-studies suggest that the sociology departments (at least those considered) were formed and supplied with a mixture of academics (professionals with an exclusive academic background) and apparatchiks (professionals that also had important careers within the party bureaucratic apparatus).

\section{Epilogue}

The 'fortunate life' of sociology in Communist Romania was to be concluded after only a decade. The short timeframe in which sociology was fully re-institutionalized never allowed sociology to develop into a critical discourse on modernization. This situation was also influenced by the

\footnotetext{
13 NAR, fund Romanian Communist Party Central Committee - Cadre Section, file C/1216, passim. ${ }^{14}$ NAR, fund Romanian Communist Party Central Committee - Cadre Section, file C/1560, passim. 15 NAR, fund Romanian Communist Party Central Committee - Cadre Section, file I/746, passim.
} 
ambiguous relationship established between the discipline and politics (mainly due to the intricate process that lead to its re-institutionalization), but also by the manner in which Miron Constantinescu imagined the new discipline, as an instrument intended to serve the regime's claim to scientific knowledge. This peculiar framework that sociology articulated and developed generated specific tensions between the professionals and the political deciders, the first rarely managing to supply the bureaucratic apparatus with more than dispersed and inconclusive data, the latter being rather reluctant and evasive in regard to the beneficial effects of these data. Several other circumstances (political, culturalideological, and biographical) influenced and precipitated the discipline's new marginalization. In 1970, the Academy of Social and Political Sciences, assimilating the Romanian Academy's prerogatives and infrastructure (in the field of social sciences) was established under the direct subordination of the Romanian Communist Party's Central Committee ${ }^{16}$. Initially, the appointment of Miron Constantinescu as the new President of the Academy of Social and Political Sciences (ASPS), and the establishment of a distinct Section of Sociology within the Academy were both beneficial and favourable circumstances. But the subsequent evolution sealed the increased control of the communist regime over the social sciences in general, and sociology in particular. One year later, Romania's cultural policies were subjected to a major, ideological reorientation, following the launch of Nicolae Ceaușescu's famous 'July Theses' - a mini 'Cultural Revolution' that implied the return of dogmatism, conformity, and the dismissal of every attempt at autonomy (Verdery, 1991). But a decisive circumstance in this process was the premature death of Miron Constantinescu (July 1974), which denied sociology the support and influence of party officials and of the decisionmaking bodies (Mihăilescu and Rostás, 2007). As a result, a gradual decline was imminent. In the following years, the research infrastructure was dismantled, while in 1977 the study of sociology was restricted to post-graduate curricula (Costea et al., 2006).

\section{REFERENCES}

Bădina, O. (1970a). Research Center for Youth Problems - Bucharest. The Rumanian Journal of Sociology, VI:63-71.

Bădina, O. (1970b). Le cadre institutionnel de l'étude scientifique de la jeunesse en Roumanie. Revue roumaine des sciences sociales. Série de sociologie, 14:97-108.

16 Decree no. 121/March 18, 1970 regarding the founding of the SRR's Academy of Social and Political Sciences, in Buletinul Oficial, Year VI, no. 22, I Part, March 18, 1970, p. 130. 
Bărbat, Al. (1970). Sociological Activity Carried on by the Department of Economy of Agriculture and Statistics at the "Al. I. Cuza" University, Iassy. The Rumanian Journal of Sociology, VI:127-129.

Betea, L. (2011). Lucrețiu Pătrășcanu. Moartea unui lider comunist [Lucretiu Patrascanu. The Death of a Communist Leader]. București: Curtea Veche.

Blaga, D. (2012). Tatăl meu, Lucian Blaga [My Father, Lucian Blaga]. București: Humanitas.

Boia, L. (2011). Capcanele istoriei. Elita intelectuală românească între 1930-1950 [The Pitfalls of History. The Romanian Intellectual Elite between 1930-1950]. București: Humanitas.

Bosomitu, S.. (2015). Miron Constantinescu. O biografie [Miron Constantinescu. A Biography]. București: Humanitas.

Bugnariu, T., Herseni, T. (1964). Școala sociologică de la București [Bucharest Sociological School]. Contemporanul, 42(940).

Cernea, M. (1970). Sociological Investigations Carried out by the Institute of Philosophy. The Rumanian Journal of Sociology, VI:45-62.

Constantinescu, V., Grigorescu, P. (1970). The Bucharest University's Sociological Activity in the Realm of Education and Scientific Research. The Rumanian Journal of Sociology, VI:25-31.

Costea Ș. (coord.), Cristea I., Dumitrescu D., Larionescu M., Stanciu L., Tănăsescu F. (2006). Istoria sociologiei românești [The History of Romanian Sociology]. București: Editura Fundației România de Mâine.

Costea Ș. (coord.) (2001). Sociologi români. Mică enciclopedie [Romanian Sociologists. A Brief Encyclopedia]. București: Expert.

Cotoi C. (2011). Jottings on the History of Romanian Sociology. Studia UBB. Sociologia, LVI (1):135-149.

Dobre F. (coord.), Bejenaru L. M., Cosmineanu-Mareș C., Grigore M., Ilinca A., Ionel O., Ionescu-Gură N., Neagoe-Pleșa E., Pleșa L. (2004). Membrii CC al PCR. 19451989. Dictionar [The Romanian Communist Party Central Committee's Members. 1945-1989. A Dictionary]. București: Editura Enciclopedică.

Ianoși I. (2012). Internaționala mea. Cronica unei vieți [My International. The Chronicle of a Life]. Iași: Polirom.

Iordăchel I. (1970). The Activity of the Department of Sociology of the Academy of Social and Political Education "Ștefan Gheorghiu" under the CC of the Romanian Communist Party. The Rumanian Journal of Sociology, VI:33-36.

Kallós N., Roth A. (1970). Achievements and Prospects in the Activity of the Sociological Laboratory of the "Babes-Bolyai" University, Cluj. The Rumanian Journal of Sociology, VI:123-125.

Keen M. F., Mucha J. (1994). Eastern Europe and Its Sociology, In Keen M. F., Mucha J. (eds.) Eastern Europe in Transformation. The Impact on Sociology. London: Greenwood Press, pp. 1-10.

Kolaja J. (1974). Notes on the Romanian Sociology. Acta Sociologica, 17:78-82.

Mihăilescu I., Rostas Z. (2007). Dialog neterminat [Unfinished Dialogue]. București: Curtea Veche. 
Momoc A. (2012). Capcanele politice ale sociologiei interbelice. Școala gustiana între carlism și legionarism [The Political Pitfalls of Interwar Sociology. Gusti's School between "carlism" and "legionarism"]. București: Curtea Veche.

Rostas Z., Stahl. H. H. (2000). Monografia ca utopie. Interviuri cu Henri H. Stahl [Monography as Utopia. Conversations with Henri H. Stahl]. București: Paideia.

Schifirneț C. (1999). Treizeci de ani de cercetare științifică a tineretului. Centrul de studii și cercetări pentru problemele tineretului [Thirty Years of Scientific Research on Youth. The Center for Studies and Research on Youth Problems]. Sociologie românescă, 1:137-142.

Shalin D. (1978). The Development of Soviet Sociology, 1956-1976. Annual Review of Sociology, 4:171-191.

Ștefănescu Ș. (coord.) (1978). Enciclopedia istoriografiei românești [The Encyclopedia of Romanian Historiography], București: Editura Științifică și Pedagocică.

T. B. (1962). Activities of the National Sociological Committee. The Romanian Journal of Sociology, I:225-229.

Tismăneanu V. (2004). Criza sociologiei românești [The Crisis of the Romanian Sociology], In Scopul și mijloacele. Eseuri despre ideologie, tiranie și mit [The Purpose and the Means. Essays on Ideology, Tyranny, and Myth]. București: Curtea Veche, pp. 159-172.

Vorisek M. (2008). “Antagonist, Type, or Deviation"? A Comparative View on Sociology in Post-War Soviet Europe. Revue d'Histoire des Sciences Humaines, 18:85-113.

Verdery K. (1991). National Ideology under Socialism. Identity and Cultural Politics in Ceausescu's Romania, Berkeley: University of California Press.

Weinberg E. A. (2004). Sociology in the Soviet Union and Beyond. Social Enquiry and Social Change. Aldershot: Ashgate.

Zemtsov I. (1986). Soviet Sociology. A Study of Lost Illusion in Russia under Soviet Control of Society. Fairfax: Hero. 